\title{
National Identity As Political Ideology
}

\author{
Zdenka Milivojevic
}

\section{Introduction'}

The events of 1990 and 1991 represent a historical turning point in the development of former Yugoslavia. That Yugoslavia, which consisted of six republics (Slovenia, Croatia, Macedonia, Bosnia-Herzegovina, Montenegro, and Serbia), had been an example of a relatively developed multi-ethnic socialist state; but from that time its former republics began to separate into ethno-national states, and thus Serbia and Montenegro, sharing an identical national-political ideology, formed the "new" Federal Republic of Yugoslavia. The League of Communists of Yugoslavia, up to that point the largest ideological-political institution in the land, disappeared from the political scene. Its functionaries divided off into their respective ethno-national republican parties, whose basic political motto could be expressed in two words-"national democracy." The ideological mechanisms (the political power of an elite, political monopoly, and political privilege) which became characteristic of all these parties, regardless of their changed names, were carried over from the "old" regime, because the political leaders of these new parties, as well as the vast majority of their membership, had previously been "sociopolitical" workers -Communists. Nationalism as a transition to nationalist democracy is a process which began at that point in Yugoslavia, and up to the present day can count its successes only in numbers of victims.

The approximately 22 million inhabitants of former Yugoslavia belonged, according to the census of 1981, to 24 different nationalities (see Table 1). ${ }^{2}$

Zdenka Milivojevic is a researcher at the Institute for Sociological Research, Faculty of Philosophy, University of Belgrade and a member with Argument Agency, Belgrade.
The two primary factors contributing to the homogenization of such an ethnically diverse population were: "brotherhood and unity," a form of politically imposed collective identity; and "self-management," a specific type of socioeconomic homogenization. Other types of collective identity such as religion and nationality were politically marginalized up until the end of the 1980s. Individual rights in former Yugoslavia were thus converged with collective rights, while the "nation," that is, its federal units, according to the 1974 Constitution, had legal status; a fact which was later shown to be a key contributing element of political support for the destabilization and collapse of Yugoslavia.

An overall portrait of the Yugoslav peoples would also include their unequal cultural, economic, and social level of development-and, indeed, the territories of the old Yugoslavia were full of extreme contradictions on all levels. The culturally and economically developed "European model" of the north contrasted with the southern, undeveloped "Byzantium." In between lay the geographical, political, economic, and cultural middle-the "Belgrade region," where, fortunately, no ethno-national or nationalistic homogenization has managed to make

\section{Table 1:}

1981 Yugoslavian Census Data

\begin{tabular}{lr} 
Nationalities & \% Share \\
Montenegrins & 2.58 \\
Croats & 19.75 \\
Macedonians & 5.97 \\
Slovenes & 7.20 \\
Muslims & 8.20 \\
Serbs & 36.30 \\
Albanians & 7.20 \\
Those who declared & \\
\multicolumn{1}{c}{ themselves Yugoslavs } & 5.44 \\
Others (Hungarians, etc.) & 7.36 \\
Total & 100.00 \\
&
\end{tabular}

any inroads, even today. The "Belgrade region" constitutes the space in which, in contrast to other areas of "rump" Yugoslavia, the former identity of former Yugoslavia-an identity of ethnic mix and political pluralismhas, on the whole, been preserved.

The end of the 1980s and the beginning of the 1990s was a period when nation and territory emerged as key political components of collective identity. The political ideology of "brotherhood and unity" was radically transformed, and in its place the ideology of defence of the national essence, national interest, and national borders, which up until that time had been only administrative technical questions, took its place. At the social level, however, the influence of the previous political ideology of brotherhood and unity was such that the question of ethno-national belonging, in everyday, more or less routine relations (among family, neighbours, friends, and workplace associates) did not have great significance. The years 1990 and 1991 saw the opening of a clearly visible chasm between the newborn nationalistic ideology of governments and the nature of everyday interpersonal relations of members of different nationalities.

In other words, everyday interpersonal relations still maintained the characteristics of brotherhood and unity, just as efforts were being undertaken to impose a new type of collective identity - nation and territory-and to establish it as the new political ideology, on a large scale and with all available means. It was precisely that gap between the ethnonational political ideology of the governing powers and the nature of everyday interethnic relations and behaviour of ordinary people, although of relatively short duration, which provides a clear indication of the origins of ethnic conflicts. After that brief interval, ethno-national political propa- 
ganda, initiated by some intellectuals and by the government in Serbia, and in other republics, began to intensify and to attract larger and larger numbers of supporters among the population. After the breakdown of the federal political leadership of former Yugoslavia into republican ethno-national leaderships (that is, political elites), nationalist tensions heightened rapidily and the ethnocultural division of the population accelerated dramatically. The multinational population of former Yugoslavia therefore began to divide along lines of those who more or less accepted predatory nationalist ideologies and those who either ignored them or resisted them.

The point at which there was a distinguishable differentiation between the nationalist ideology of government and the quality of interethnic relations among the population coincided with the most vigorous nationalistic campaigns in which the media showed themselves to be the essential agent of communication between government and people. Aided by newly emergent, vigourous "defenders of the nation," nationalist media propaganda attracted supporters among the population and served to create refugees. The first refugees to arrive in Serbia from Croatia were recorded in September, 1990, and from that time their number has increased constantly. Refugees from the period September, 1990, to May, 1991 were on the whole made refugees by the dramatic influence of media propaganda in service to ethnonational political ideology, because the primary reasons for their departure was media-induced fear. For those refugees who departed between May, 1991, and the end of that year, the main reasons stated for leaving their place of permanent residence became, besides fear, loss of jobs, threats to individuals and families, and general endangerment of life.

For this reason refugees are living witnesses to the process by which the media promote ethno-national identity as a political ideology, and how, at that time, all types of interethnic relations in ethnically mixed areas and beyond began to be systematically crushed. The government and the people, thanks above all to the media, gradually established a correspondence, and the discrepancy between ideology and interpersonal relations began to disappear. This merging of views was based, on the one hand, on the (rather low-level) political culture of the citizenry ${ }^{3}$ and their unpreparedness at the right moment to realize what was really happening and what the consequences would be; and on the other hand, on the narrow interests of nationalist political elites to acquire or maintain republican power. In addition to the low level of political culture, the socially urgent need for reconstruction of the economy, because of the drastic consequences for the standard of living set off by the economic and political crisis, exacerbated the dissatisfaction of the population and unleashed its irrational energies. It is precisely in such a political and social atmosphere that the media can successfully intervene between government and people, and the political nationalization of discourse through media becomes an effective model for the reaffirmation of ethno-national spirit and the intensification of national feelings. The causes of ethno-nationalistic war in the territories of the former Yugoslavia can be found at all levels: from international politics and internal relations of domestic political elites, to the concrete interethnic relations of the population. Their relative importance can be distinguished sequentially in time. The purpose of this work, however, is to shed light on the process of the internal political production of ethno-nationalist war. This analysis of the "process of mediation" between power holders and ethnically mixed communities views the individual as having different types of roles and engaging in various kinds relationships.

One of the essential questions of this work is the reasons for and the timing of the onset and acceptance of nationalistic ideologies. The text is based on data obtained through research on refugees from Croatia in 1991.4
The Process of Destruction of Ethnically Mixed Communities in The Former Yugoslavia

"Brotherhood and unity," which began as a political category, created a community which then began to break down according to the category of membership in an ethnic group. The radical transformation of one form of integration into another, contradictory one, over a short period of time, raises the question of the operative efficacy of individual factors. The dynamic with which the ideology of brotherhood and unity crossed over into interethnic war speaks not so much to the theory of a fertile nationalistic latent structure as the basis, but rather to the efficient joining together of diverse political interests, the symbolic order, and the specific type of individual isolated political culture as the principle reason for war on the geopolitical territory of Yugoslavia. Further, it speaks not to the equilibrium of its significance and power but rather emphasises above all the mobilizing factor which insures an indispensable homogeneity and dynamic, and at differing intervals.

The issue of resistance on the part of the ethnically mixed community to the tendency of destruction, from outside or internally, however, leads to the question of its constitutive elements and the nature of micro-factors of integration.

Within this approach to under. standing the reasons for interethnic destruction, it must be kept in mind that interethnic conflicts, at a concrete level, were as a rule initiated by participants recruited from groups of sports fans, dressed in uniform overnight, and paid to become "national defenders," those who would, in their ethnically mixed environment, defend their "nation" while attacking "the other." The sports fan, symbolizing the spirit of collectivity, provides the particular type of energy capable of expressing and acting on aggression. This was not entirely coincidental, for traditionally fan euphoria at sports matches between teams from different republics 
often had a nationalistic tone in former Yugoslavia.

The transformation of the individual from a non-ethnic self-manager into a vigorous ethno-nationalist began, under pressure of the media's manipulation of information, with the closing of media borders between republics. Nationalistic propaganda in ethnically mixed regions in Croatia brought out "self-invited" protectors of the nation, nationalist volunteers from all regions of Serbia and Croatia, to defend local residents from each other: a Serbian housewife from a Croatian housewife, a Serbian neighbour from a Croatian neighbour, a Serbian brother from a Croatian brother. The institutionalization of nationalism began with the firing of Serbs from workplaces in areas where Croats constituted the majority of the population, and conversely the firing of Croats from workplaces in areas where Serbs were in the majority, or where they held positions of political responsibility. The standard socialist distribution of power and decision-making, in accordance with principles of the political rotation of cadres, ${ }^{5}$ was in this respect operative, so that it was not even necessary to take a formal institutional decision. Such decisions were, only later, retroactively entered into the books. Municipal politicians, locals of political standing, were coerced (whether or not they wanted to) into adhering to the ethno-national division of the town or village in which they lived-and this became a life or death question. If the members of the other ethnic group did not kill him, the members of his own would kill him as a traitor. With the destruction of ethnically mixed areas in this way complete, the only remaining question was the ethnic cleansing of the place.

Although within former Yugoslavia there existed several types of cultural models which were very different from one another, the relatively common characteristic of all ethnic groups was the decisive basis for the transformation to nationalism. A systematically developed authoritarian social character along with a discernible mentality, latent nationalistic tension, and worsening conditions of existence guaranteed the success of a manipulation toward the option of war. War was the consequence of the destructive influence of nationalistic ideology and depended not only on the effectiveness of the manipulating agent, but also on the latent structure of society, the micro-community.

The extent to which the ethnic community was homogeneous and the nature of influence of specific factors on the destruction of that community can best be seen from the results of empirical research carried out with refugees who left their homes prior to the summer of 1991, directly before the outbreak of the worst armed conflicts. ${ }^{6}$

The theoretical question with which we were unavoidably confronted in this analysis was: can the condition of being or becoming a refugee be considered a form of migration, if the primary motive for departure stems from an undefined fear (as expressed by the first refugees of 1990), or from direct threat to life (as experienced by those who came later, in the summer of 1991)? Migrants by definition always have a larger possibility of rational choices and voluntary decisions, while for refugees such choices are severely limited. It is a particular type of coercion that forces one to become a refugee, which differs from the reasons for voluntary migration, in terms of the intensity of endangerment to one's existence. Thus the refugee must be considered distinct from the migrant, and therefore the theoretical concepts concerning migrants are inadequate for the analysis of refugees. The only similarity between refugees and voluntary migrants lies in the fact that members of both groups become "second class citizens" in the milieu in which they settle, and their status becomes and remains a part of their social "identity card" for succeeding generations. The absurdity of this case is that these individuals are refugees within the former Yugoslavia, irrespective of ethno-national identity, and are thus refugees within their former homeland. Moving to their "native" ethnic republic does not, however, lead to ethno-national homogenization, but rather to an increase in intra-ethnic tensions, and even to conflicts. The assimilation of Serbian refugees from Croatia among "old Serbian residents of Serbia" is hindered by the differences between the two groups, which are manifested at several levels: from everyday habits (in workplaces and elsewhere) to language. This confirms the notion that the social impulses for conformity within everyday life, no matter what the cultural milieu, are sufficiently strong that national identity becomes overshadowed. Therefore, ethno-national predatory behaviour can become a basic part of everyday interpersonal relations only through politically manipulated transformation.

\section{How Did They Live Together Before?}

The historical memories of the population concerning brutal interethnic (and inter-religious) conflicts during the course of world war has often been referred to by some Serbian intellectuals as the key proof for the theoretical interpretation of reasons for the flight of refugees today. However, the data from our research indicate that contemporary ethnic conflicts did not start spontaneously, as a result of integration of personal and group experience in interethnic threat over the course of time from the Second World War to the present day, nor did the historical memory of "Ustasa genocide against the Serbian people in the Second World War" provoke a new wave of killing. But it is certain that "collective memory" of this act was the articulated target of the media for the purpose of strengthening Serbs' ethno-national feelings. It is also certain that its articulation as a basic element for nationalizing discourse arose from a certain latent structure through to everyday interpersonal relations, as will be shown later.

A total of 60.3 percent of the informants in this study indicated that in interethnic relations in the postwar period (i.e, after the Second World 
War) there was never any sort of division; 60.2 percent indicated that there was never any interethnic intolerance; 77.7 percent said there were never ethnic conflicts at the personal level, and 83.9 percent said there were never any ethnic conflicts at the group level. At the same time, 39.7 percent of the informants indicated that there were interethnic divisions in the postwar period; 39.8 percent that there was interethnic intolerance; 22.3 percent that there were personal interethnic conflicts, while 16.1 percent said that there had been interethnic group conflicts. Careful analysis of these data, however, suggests that the latent structures for the development of ethnic conflicts in ethnically mixed areas were already present, but not to such a degree that one could expect their spontaneous transformation into nationalistic conflict or war. Informants in this study typically characterized the breakdowns in interethnic relations in the period after the Second World War in the following terms:

... when the opportunity arose, Croats would withdraw to their side, Serbs to theirs ... after the events at Kosovo, Croats considered that Albanians should be given their republic, while Serbs believed the opposite, and there would be arguments, especially at work. It rarely came to fisticuffs, and it would always be outside, after working hours, so nobody knows how often this happened ... [a pensioner from Vukovar].

... intolerance was always initiated from the top: usually there was some political event which the government was responsible for, and because of which people would quarrel, and divide according to ethnic identity ... [an economist from Zadar].

These expressions of these refugees reflect the political nationalization of discourse organized by the media which began the process of political and nationalist transformation of the self-consciousness of the "self-managing" individual. Here it should be mentioned that the "self-manager" was only declaratively a political sub- ject of the melting-pot; while nationalist ideologies have as their political subject the authentic nationalist. Nevertheless, the "self-manager of brotherhood and unity" finally realized, after 40 years of manipulation, that all decisions were in any case made outside the workers' councils. This was one of the factors that gave birth to resistance to the socialist regime, and was yet another source of dissatisfaction and mobilization of irrational energy. The concept of "worker" evolved through "working people" to arrive at "nationalist" and "nationalistic interest." One form of manipulation was replaced by another. The filtered political category of "self-manager" encouraged the individual to learn conformity to the crowd, to government, and to prevailing policy, and left the individual without a suitable social role, without a wider social framework for collective identity. At the same time, as a model of "political literacy," the concept of the "self-manager" was based on the principles that authority belonged to its adherents, power accrued to its supporters and to the obedient, the political subject conceptualized according to political object, and sources of information according to the needs of the (un)informed. The possibility (and the incentives) for the self-manager to become a citizen were successfully cancelled out through political intervention.

From the data it can also be seen that the character of interethnic relations after the Second World War up until the present reflected a significantly greater measure of orientation toward "brotherhood and unity," but that they also became, in a relatively hidden way, oriented to ethnic tension. The first level of interpretation of this contradictory fact is that "Yugoslavism" and nationalism both had the foundation, and therefore the potential, to be developed further. The second level of interpretation focuses on the differences in the foundations of Yugoslavism, on the one hand, and of ethnic tensions, on the other. The concept of Yugoslavism, at first only through ideological propaganda and political directives, penetrated all interpersonal relations, and became a way of life, a peculiarly Yugoslav reality. The population of former Yugoslavia, according to the data, was to a very large extent unburdened with the question of ethnic affiliation.

Without disputing the possibility of the persistence of "historical memory" as a latent structure, we have to emphasize nevertheless that in such social and political circumstances it did not appear to play a role in the spontaneous (internal) provocation of conflict because, for one thing, the number of those who had been witnesses to those events was steadily diminishing (some 40 years had elapsed), and for another, the remaining sources through which this "memory" could continue and be sustained were neither current nor widespread. Moreover, ethno-national conflicts within ethnically mixed communities did not erupt in all ethnically mixed areas at the same time. These circumstances notwithstanding, "historical memory" has been brought directly into political propaganda, and, once conflicts escalated, used as a supplementary motive for ethnic hatred and ethnic defence.

\section{Interpersonal Relations Prior to Exile}

We attempted to trace the mechanisms of interethnic destruction through the informants' testimony concerning the quality of relationships in everyday life with family, friends, neighbours, and workplace associates. It began, our respondents noted, "with the distancing, the cooling of relations," and "it ended up with the shelling or mining of houses, with being forced out."

Our research also confirmed at this level that the functioning of the Yugoslav "melting pot" (interethnic integration under the influence of the ideology of brotherhood and unity) was exceptionally successful: more than four-fifths ( 86.0 percent) of the informants testified to good relations with neighbours and with members of other ethnic groups, as many as 95.1 percent had well developed friendships, and more than two-thirds $(66.5$ 
percent) had relations with relatives who were members of other ethnic groups-primarily on the basis of ethnically mixed marriages. These findings challenge to a significant degree the theory about historical continuity of ethnic conflicts and speak to the thesis that current ethnic conflicts did not begin spontaneously, as a continuity of genocidal hatred, but rather were somehow artificially provoked or induced. The culmination of interethnic disintegration in violent armed conflicts had a decisive influence on the worsening of relations between members of different nationalities. Thus, 58.8 percent of informants testified that relations with neighbours had deteriorated, while a similar number found that friendships with members of different nationalities had been damaged (58.5 percent); family relationships, on the other hand, which tend to be strongest, were most successfully sustained-although every fifth informant (21.1 percent) confirmed that even family relationships had suffered.

\section{Ethnic Conflicts-the Beginning and the Escalation}

Current interethnic conflicts began to intensify during the pre-election campaign at the time of the first postwar multi-party elections in Croatia, in April, 1990. That campaign was identified by 14.9 percent of the informants as a contributing factor to conflict. The aggressive campaign of the victorious party, the Croatian Democratic Union, and particularly the framework of that party's electoral programme-creation of an ethno-national state with a diminishing of political rights for minorities-resulted in the establishment of a political authority which evoked suspicion among members of other ethnic groups. About one-third of the informants in this study ( 35.5 percent) mentioned this as a reason for the worsening of interethnic relations, and the potential realization of the party's programme, which called forth the active resistance of the Serbian population (the events of the so-called "log revolution" in the Knin region), is the next reason given by 8.2 percent of the informants. Conflicts burst into flame during the first quarter of 1991 (according to 7.7 percent of the respondents), and intensified in the second quarter (17.1 percent) when open armed conflict began.

The first refugees did not emerge as a result of the continuation of ethnic conflicts, but rather as a product of media-induced fear. In the first wave, that is, up until May 1, 1991, according to the data obtained in this study, the main reason for departure was the media coverage of Martin Spegelj, a former General of the Yugoslav People's Army and a current General of the Croatian Army-as he negotiated the purchase of weapons with which, to paraphrase his remarks, "everything that is Serbian will be killed."

The sharpening of interethnic conflicts in the months in which the number of refugees rose dramatically was manifested in different ways. A direct motive for departure was, therefore, an escalation from simply "fear" itself to "fear of war," "fear of revenge," "fear for one's life." In conditions of interethnic conflicts, fear, as an irrational category, is structured at two essential rational levels: the historical and the current political. At the same time, (the individual's) fear, at the local level of ethnic conflicts, is subjected to the influence of all kinds of anomic effects. These include: changes in the system of government, police and law; changes in leading personnel in the economic and social sectors; limitation of negative freedoms (movement and work, social security, etc.); symbolic and cultural self-identification (flags, crests, language, media); as well as different forms of deviant behaviour (from abuse of the vulnerable to robbery, theft, and violence).

The question that many citizens of the former Yugoslavia ask themselves is: who is to blame for the situation in which we now find ourselves? We felt it was necessary to pose this question about the "guilty" party to our refugee informants, but within the framework of two assumptions. First, anyone who lived through the current situation and through concrete personal (family) tragedy, such as exile, would have his or her representation of who is responsible for it. Second, we wanted to find out if and to what extent refugees merged radicalization with generalization, and whether they would consider the guilty party the Croatian people in general. The distribution of answers indicated that only one of every twenty informants blames the Croatian people. The majority of respondents (63.1 percent) blamed the current Croatian government, and its President, Tudjman. It is noteworthy that every fifth informant also blamed the Serbian leadership. The data for the two most commonly mentioned guilty parties (the "Croatian government" and "all political leaderships") ditfered according to the ethnic identity of the informant.

Results of research on refugees from Croatia in 1991 indicate that communal life with different ethnic groups in the same territory over many decades had those characteristics which, according to the manner of expression of ethnic identity, would be unlikely to be reversed. Rather, the characteristics of the established ethnically mixed community revealed more about the lack of civil rights and freedoms, the existence of social differences, the tendency to unlawful or wilful decisions by local authorities, that is, all other things except nationalistic tensions. Horizontal nationalistic energy was released by the interest of political elites, and distributed from top to bottom along the social vertical of the community.

The combination of underdeveloped political culture, burdensome social conditions caused by economic crisis, and the unleashing of irrational energy as a result of the precipitous fall in the standard of living, provided sufficient ground for intermediary agents to mobilize the latent structure, that is, to establish a vital "collaboration" between government and people. At the same time, the then relatively homogenous ethnically mixed community began at that point to be visited by ethno-national "volunteer" groups 
(who were to become the nationalist paramilitary groups later on) from Serbia and Croatia. Their intention was to "defend" local Serb residents from local Croat residents, and vice versa. These "newcomers" proclaimed themselves protectors of the (Serbian or Croatiant as the case may be) nation and of the national interest, while local residents, at least at the beginning, "asked" them not to come any more to "defend" them, because they did not need defending. But these Serb and Croat paramilitary "newcomers" started to threaten the local residents, to push people into supporting them. In addition to these paramilitary "newcomer" groups, "military" territorial defence groups were also formed, somewhat later (and these latter were joined by the local population regardless of their ethnic identity). During this time the Yugoslav People's Army was being gradually deserted by members of all nationalities except Serbs, Montenegrins, and Muslims (Muslims began to leave the Army only after the situation in Bosnia worsened in 1992). The resulting Yugoslav People's Army, now almost ethnically "pure" in composition, was later obliged to "keep the peace" in ethnically mixed areas. Thus began the armed destruction.

\section{National Identity: Secular Religion or Political Category}

National identity is a category which contains simultaneously within itself historical, individual-psychological, cultural, social, and political dimensions, and among which the dominance of one over the other depends on the degree of current sociopolitical pressure exerted upon it. It therefore can be manifested in different ways: as an individual feeling, as a cultural model, as social relationship, or as a collective and political category. Only in so far as the basic conceptual-subjective feeling in consciousness of ethnic belonging can be expressed, as a part of the individual citizen's legitimate private-legal dignity, then this inescapable characteristic of the individual does not have metahistorical, metacul- tural, or metasocial connotation. In every other case national identity is the instrumentalization of a privately held self-concept, and is a manipulation of those human characteristics, which in any case the individual has no choice.

Individual identity is constructed upon diverse social roles carried out more or less routinely in everyday life. Not one of these routine, everyday social roles, whether in the interpersonal sphere, working relations, or leisure time, depends upon, nor is it a function of, the person's ethno-national identity, and the nature of the individual's routine, everyday obligations does not in any respect refer to national identity. Only when ethno-national identity, "as a secular religion of the individual," is transformed into a political ideology does it become a critical precondition for the carrying out of any social role. Ethno-national identity then becomes the primary social role upon which everything else depends, and the basis of (lack of) privilege of the personality irrespective of his or her level of education, professional orientation, or some other special characteristic or quality.

\section{Model of Nationalization of Dis- course in the Former Yugoslavia}

The construction of nationalist (political and everyday) culture within the behaviour of former citizens of Yugoslavia did not begin simultaneously on all levels of society. Nationalism as a political strategy significantly preceded the lower-level cheapest street production of nationalist images and sentiments. Nevertheless, some intellectuals who manufactured "Cole Porter nationalism" were, in the span of five years, able to establish successful foundations for communication-and everything that the first ones thought up, these others justified.

The manner in which a political idea (nationalism in former Yugoslavia) begins to come alive semantically, and thus to have an impact upon individual consciousness, unfolds in a politically anticipated direction. Thus, one of the questions to be asked is the "hierarchy of factors of influence" on the conditions of realization of normative acts. In cases such as Yugoslavia, "the form of political community" is (and was) dictated by the "activity of state power," and not "the political will of the community itself." From this state of affairs, "the national idea semantically began to function above all as a destabilizer of the 'ethnic state,' that is, in the form of 'regional rebellion,' 'awakening of small nations,' and 'self-consciousness of ethnic minorities.'"7 The breakup of Yugoslavia into 'parts and unities of societies' was such that the legitimizing bases of power became weaker and weaker. At precisely this interval, the totalitarian government introduces new ruling technologies, first through new political discourse, and then through mechanisms of "controlled liberalization." Changes within political discourse provoke changes within the symbolic order and within public opinion, which begins to be pluralized: from acceptance and support of the new rhetorical project, and then further on to its practice, to its criticism, and to its rejection. In other words, the new ethno-political discourse manufactures both supporters and opponents. Supporters transform it into concrete action, while opponents remain on the margins, because their actions cannot compare with those of holders of official power and the supporters among "the wider popular masses." The collapse of "old" social connections and the establishment of new ones takes place, above all, under the influence of various communications processes.

The expressly articulated presence of nation, national interest, and national essence, and the overall nationalization of discourse in everyday speech and interpersonal relationships, began with more intensive political discussions of the meaning of national identity and the safeguarding of the national interest. The introduction of nation and national interest in everyday political rhetoric in Yugoslavia took place at the moment when an exclusively counterproductive economic policy and economic crisis 
threatened the state, and not some other nation. The republican leaderships resolved the federal government's crisis of legitimacy by evoking ethno-national spirit and national interest for their respective republics. Ethno-national interest was at first politically cloaked in ideological discussions and declarations, and then evolved into political action. The most decisively important political action that facilitated the introduction of nationalism was the closing off of the media within the republican sphere. With the internal republican isolation of the media came subsequent debates about which alphabet (Cyrillic or the level of the republic, an illusory social equilibrium. The consequences of the economic crisis, which affected all of Yugoslavia, began to be "resolved" at the level of the nation, and the blame for that crisis was laid on the other nation.

Ethno-national interest becomes identified with the territory (in this case the region of Croatia) on which people had, over a period of many years, established a system of mixed social networks, which, irrespective of national identity, functioned to the advantage of everyone. The politicization of one's own ethno-national interest through its "protection" by

\section{The symbolic order in totalitarian regimes always creates a fictive public. Real events, impregnated with ideological-political symbols, are degenerated and incorporated into a system of information/ knowledge structured on a reliably predictable public opinion.}

Latin) was to be used in the subtitles of films and for the most widely viewed programmes. After the "closing off" of the media, which was initiated following the former Yugoslav state holiday of November 29, 1989, a common Yugoslav media, for all practical purposes, ceased to exist. Viewers were no longer able to watch regularly alternating daily informative news reports from the other republican centres, which had been standard practice in the past; and now had the opportunity only to watch the daily news programmes prepared within their own republics.

The national interest, under this kind of political "protection," constitutes the misuse of historical roots and the vulgar manipulation of ethno-national feelings of the individual to the profit of political interests by those who measure national interest only in terms of protecting their own current political self-interests. Ethno-national interest projected in this way involves the politicization of the individual's origins, emotions, and personal fates, and enhances the construction of aggression. The raising of ethno-national interest to the level of policy was a political strategy for establishing, at means of brutal ethnic conflicts, which were allegedly only an act and product of defence, is an absurd indicator of the collective hysteria resulting from inadequate political integration of membership in the community, a community burdened with increased social misery brought on by a wornout and inappropriate political system, and not by some other nation. The absurdity is compounded as the politicization of ethno-national interest intensifies the misery, and predatory nationalism and ethno-national hatred grows deeper, directed not only toward the "enemy" nation but also to one's own nation. The process of ethno-national transition accompanies the disappearance of the legal state, as more massive use is made of all the resources and behaviours that in conditions of social equilibrium bear the mark of the criminal-disorganization, lawlessness, and crime.

The nationalization of discourse, which unfolded from the beginning of December, 1989, also produced militant nationalists, who supported the war as national defence and liberation. The model of homogenization by means of nationalistic discourse went out in the form "us" and "them."
Enemies are "them," that is, all other nations.

The symbolic order in totalitarian regimes always creates a fictive public. Real events, impregnated with ideological-political symbols, are degenerated and incorporated into a system of information/knowledge structured on a reliably predictable public opinion. Media commentaries, for example, as an essential part of this information system, have the task of "informing" according to the government's political requirements of the day. In this way a fictitious picture of reality was created, and a so-called "people's will" manufactured and set in motion with forcefully directed energy. This creation constituted "proof" of the legitimacy of "democratic" government. Such a fictive public eventually takes on a life of its own as an independent "authentic collective spirit."

From the moment that the empty legitimate space of power was "filled after the fall of communism, it began to be filled by the nation," that is, the nationalization of political discourse evolved, to the point at which a new reality was produced: "ethno-national reality: division and ethnic conflicts," on the basis of which further, and in more dramatic form, disintegrative processes unfolded for which the government's solution was held to be in narrowing of options to ethno-national interests. In the model of the authoritarian regime, as was the case in former Yugoslavia, nationalization of political discourse achieved a "special paradox: that in the name of which and because of which this began became a lever of its own destruction. That lever was freedom understood as the nation. The equalization of nations through freedom alone clears the path for its elevation to an idolized ideal, which becomes characteristic of a new authoritarian order. ${ }^{8}$ In the "old" socialist demagogy, people were subjected to political socialization oriented to defence against the class enemy; in the "new" nationalistic demagogy people are oriented toward defence against the enemy nation-against those who, 
only yesterday, were their closest relatives, friends, neighbours, or colleagues.

Political pluralism, within the territories of the former Yugoslavia, unfortunately coincided with the rise of ethno-nationalism, and the crucial political question concerned national borders. The matter of secession of the republics from Yugoslavia, with maintenance of what had until then been "administrative borders," resulted in growing conflict among diverse political interests of republican leaderships within the federal government. The strategy according to which residents of Croatia had to decide whether or not they wanted an independent Croatia, was ethno-nationally based: Serbs who live in Croatia did not want itthis was decided for them by Milosevic, and Croats wanted it-this was decided for them by Tudjman. Whether all Croats were really in favour of an independence state and its emancipation from the "Yugoslav prison," and whether all Serbs really wanted to remain in Yugoslavia, was a meaningful question for the republican political establishments. Both the one and the other republican government "knew" in advance what their nations would support.

\section{Notes}

1. This work is a short extract from a broader study which includes data from research with refugees from Croatia in 1991 as well as refugees from Bosnia-Herzegovina in 1992.

2. Figures are taken from Dusan Breznik, "Stanovnistvo Jugoslavije," Konzorcijum Instituta drustvenih nauka (Titograd: Chronos, 1991).

3. Podunavac, Milan. Politicka kultura i politicki odnosi (Belgrade: Radnicka stampa, 1982).

4. The project "Displaced Persons from Croatia, 1991," was carried out by the Argument Agency for Applied Political and Sociological Research (founded in 1990). Fieldwork was conducted in September 1991, at which time on the territory of the Republic of Serbia there were about 88,000 displaced persons from Croatia. The sample covers 650 informants, i.e., representatives of displaced households. According to the data of the International Committee of the Red Cross for the period SeptemberDecember 1991, the number of displaced persons from Croatia amounted to 588,000 .
Out of this number 318,000 (54 percent) resettled from the crisis areas into provincial areas of Croatia, and 270,000 into other Yugoslav Republics. On the basis of these data, as well as according to the incomplete results of the Yugoslav census of 1991, these compulsory migrations out of Croatia constitute 12.4 percent of the total population of this Republic, of which 9.0 percent is Croatian population and 44.3 percent Serbian. However, when examining the share of displaced population compared with the total number of inhabitants of the Republic of Croatia, then the Serbian displaced population totals 5.7 percent and Croatian 6.9 percent of that number. According to statistics of the High Commission of the United Nations, at the end of April 1992, the number of refugees was increasing daily and has already passed the one-million mark.

5. Those who were loyal to the old political system now became loyal to the ethno-nationalistic order, sensing that they were called to the function of being the alert guardians, formerly of "self-management," now of ethno-national interests, because that legitimized the function that they acquired in return for their moral-political capability.

6. The research included refugees from 52 ethnically mixed municipalities in the Republic of Croatia, involving 153 settlements of urban and rural type. In more than two-thirds of the municipalities (68.4 percent), refugees were recruited from the population which represented the ethnic minority in these municipalities; in one-fifth (21.1 percent) the potential refugee population was the majority in the municipality, while in 10.5 percent there was a relative ethnic balance. More than two-fifths (44.9 percent) of the members of refugee households, for which representatives were interviewed, represent an indigenous population (that is, they resided in their place of birth); more than one-third (34.6 percent) were intra-republican migrants; while one-fifth had come from outside the Republic of Croatia to settle there.

From the total number of all members of households in our sample in exile, 46.6 percent were male and 52.9 percent were female, and in terms of age cohort, the largest number were between the ages of 31 and 40 years. With respect to nationality, 87.9 percent were Serbs, with the remaining belonging to other ethnic groups-which is not necessarily an indication of mixed marriages, since the number of married and unmarried was almost the same: $\mathbf{4 3 . 1}$ percent and 41.5 percent respectively.

7. Djindjic, Zoran. Jugoslavija kao nedovrsene drzava (Novi Said: Biblioteka matice srpske,1988), p. 9.

8. Kovacevic, Djuro "Jugoslavija: osvajanje ili gubitak istorije," Zbornik Raspad Jugoslavije produzetak ili kraj agonije (Belgrade: Institut za evropske studije, 1991), p. 11. J

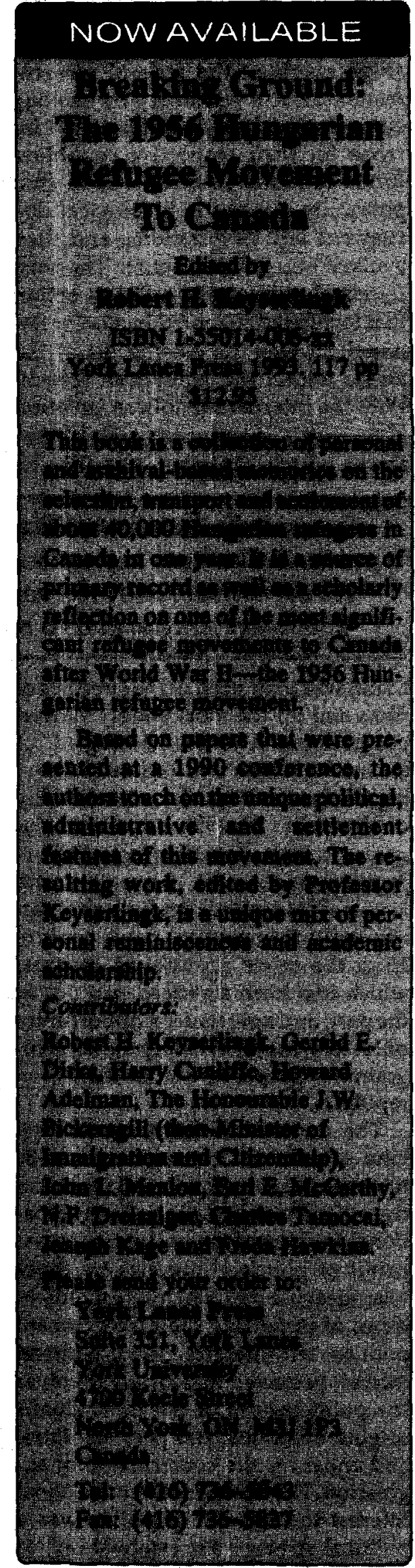

